\title{
The Role of Fiscal Instruments in Environmental Policy
}

\author{
KATRI KOSONEN \\ GAËTAN NICODÈME
}

\begin{abstract}
CESIFO WORKING PAPER NO. 2719
CATEGORY 10: ENERGY AND CliMATE ECONOMICS

JULY 2009
\end{abstract}
An electronic version of the paper may be downloaded
- from the SSRN website: Www.SSRN.com
- from the RePEc website: $\quad$ www.RePEc.org
- from the CESifo website: $\quad$ www.CESifo-group.org/wp




\title{
The Role of Fiscal Instruments in Environmental Policy
}

\begin{abstract}
Environmental protection is one of Europe's key values. The EU has set clear policy objectives to achieve its environmental goals. The EU has favoured market-based instruments, among which fiscal instruments to tackle the climate change problem. This paper takes a policy-making perspective and provides an overview of key issues on the role of fiscal instruments in energy and environmental policies. It describes fiscal instruments as costeffective means to promote environmental goals and highlights in which cases taxes and other types of fiscal instruments can usefully complement each other to achieve environmental target.
\end{abstract}

JEL Code: H23, Q38, Q48, Q58.

Keywords: taxation, environmental policy, VAT, fiscal incentives.

Katri Kosonen

European Commission

katri.kosonen@ec.europa.eu
Gaëtan Nicodème

European Commission

gaetan.nicodeme@ec.europa.eu

June 2009

The views expressed in this article are those of the authors and do not necessarily reflect the official position of the European Commission. The authors thank Pol Vermote for useful comments. Remaining errors or omission are those of the authors only. Contact: katri.kosonen @ ec.europa.eu and gaetan.nicodeme @ ec.europa.eu.

(c) European Communities, 2009. 


\section{INTRODUCTION}

Environmental protection is one of Europe's key values. The EU has set clear policy objectives in the areas of energy and climate change and has committed to achieve ambitious targets with respect to energy savings, reductions of greenhouse gas emissions (GHG) and deployment of renewable energy sources by 2020. However, aggregated projections of EU-27 for 2020 show that, even if the additional measures currently planned by Member States are adopted and fully implemented, greenhouse gas emissions will increase between 2010 and 2020, reaching a level approximately $2 \%$ higher than in 2005, and only $6 \%$ below their 1990 level. This is a significantly higher level than the unilateral commitment of a $20 \%$ reduction, compared to 1990 levels, decided by the European Council in December 2008 (see EEA, 2007). Without public intervention and the strong commitment of all actors, these ambitious objectives cannot be reached.

The EU has increasingly favoured economic or market-based instruments ("MBI”) such as indirect taxation, targeted subsidies or tradable emission rights - for such policy purposes. The more intensive use of MBI has also been advocated in the EU 6th Environment Action Programme (6th EAP) and the renewed Sustainable Development Strategy as well as the renewed Lisbon Strategy for Growth and Jobs. The Green Paper on market-based instruments (European Commission, 2007) explored further the options for a more intensive use of market-based instruments in different areas of environmental policy at both Community and national levels.

This paper provides an overview of key issues on the role of fiscal instruments in energy and environmental policies. It describes fiscal instruments as cost-effective means to promote environmental goals and highlights in which cases taxes and other types of fiscal instruments can usefully complement each other to achieve environmental targets. Fiscal instruments are here understood in a broad sense. They comprehend all economic instruments of fiscal nature - that is via the use of the fiscal system - as well as direct subsidies that 
provide incentives to shift from environmental harmful activities towards cleaner and more sustainable alternatives. In economic terms, the goal is to internalise externalities (see box 1). Fiscal instruments can be divided into two main categories: tax instruments and subsidies.

Taxes and charges levied on goods directly or indirectly linked to polluting activities. They can be defined as "all compulsory, unrequited payments whether the revenue accrues directly to the Governments budget or is destined for particular purposes" (European Commission, 1997). Taxes and charges are often labelled pricing instruments, as they impose a price on the environmentally harmful aspects of production or consumption and thus aim at influencing consumer behaviour by increasing prices. The term market-based instruments refers to all the instruments that act through the market mechanism. They include taxes, charges and tradable permits (emissions trading schemes).

Subsidies accorded directly or through the tax system to encourage producers and consumers to choose the inputs and goods that have favourable properties from the environmental perspective. In contrast with taxes, they provide incentives by decreasing the price or purchasing costs of a product. Since these subsidies are meant to provide incentives for production and purchase of goods with favourable properties, they are often labelled as fiscal incentives in political language. This terminology will be used also in this paper for the sake of brevity. Fiscal instruments of this second category can be further divided into three different types: (a) Direct subsidies, (b) Incentives given in direct taxation (personal income or corporate taxation) in the form of tax credits or allowances, (c) Differentiation of the tax rates in indirect taxation (VAT/ excise duties).

In the remainder of this paper, chapter (2) discusses the role of fiscal instruments in energy and environmental policy. Chapter (3) discusses how taxes can be complemented with other fiscal instruments. Chapter (4) focuses on reduced VAT rates and their role as fiscal instrument. Chapter (5) deals with subsidies and direct tax incentives for promoting EU 
environmental objectives. Chapter (6) compares reduced VAT rates with direct fiscal incentives. Conclusions follow.

\section{THE ROLE OF FISCAL INSTRUMENTS IN ENERGY AND ENVIRONMENTAL POLICY}

\subsection{Advantages of fiscal instruments as policy instruments}

Compared with regulatory instruments (standards, quotas, product bans) the main advantage of taxes and other market-based instruments is efficiency. Pollution taxes induce each polluter to reduce the pollution up to the point where the marginal cost of pollution abatement is equal to the tax. In this way the costs of reaching a given environmental target are minimized (static efficiency). Moreover, polluters have more flexibility to choose the level and the method of abatement. Imposing taxes and charges generally requires less detailed information than regulation and thus entail lower administrative costs. Market-based instruments set a price on each unit of pollution / emissions and thus induce firms to constantly seek new pollution abatements possibilities and to invest in less-polluting technologies. This is a powerful incentive for innovation (dynamic efficiency). Taxes and charges are also effective instruments to change consumers' behaviour to a more sustainable direction. They provide price signals that change the relative prices of "dirty" and "clean" consumption goods and induce consumers to choose environmentally-friendly goods. They are essential instruments for the "getting prices right" policy of the Community Sustainable Development Strategy ${ }^{1}$.

The cost-effectiveness of taxes and other price instruments may be reduced, however, when fiscal interactions, that is the effects of environmental taxation in factor markets (labour, in particular), are taken into account. These effects are usually ignored in the first-best, partial equilibrium framework, in which environmental taxes are traditionally analysed (see box 1).

\footnotetext{
${ }^{1}$ Goulder and Parry (2008) present interesting evidence from a few US studies about pollution abatement costs in case different policy instruments are used. According to the estimates pricing instruments (emission taxes, fuel taxes, or tradable permit systems) would reach the same level of pollution abatement with considerably lower costs (in the range of 40-95 \%) than regulatory instruments (technology mandates or performance standards).
} 
In the presence of distorting taxes the introduction of an environmental tax entails a welfare cost as far as it reduce labour supply by increasing consumer prices and thus reducing real wages $^{2}$. According to Parry and Oates (1998) this negative welfare effect, labelled "tax interaction effect" in economic literature, could be substantial even in the case of only slight reduction of labour supply. This is because the labour market forms usually a large share of national economies.

This analysis would be partial, however, if it did not take into account also another property of tax instruments (and auctioned tradable permits), namely their capacity to raise revenues and the fact that these can be used to reduce other distorting taxes in the economy, notably taxes on labour (which is the basic idea of green tax reforms). Can this revenue recycling then remove the negative welfare effect of environmental taxes? The answer of economic literature tends to be "no": under plausible assumption the tax interaction effect is always bigger than the revenue recycling effect, and environmental taxes do not represent a win-win option, but always entail some economic costs. This is because replacing taxes with a broad base, such as labour taxes, with more narrowly-based taxes (environment) usually opens up more substitution possibilities and thus increases the excess burden of taxation ${ }^{3}$. This implies that the strong form of "double dividend" associated with environmental tax reforms does not hold ${ }^{4}$. The issue is controversial in economic literature, and some authors argue that in the presence of imperfect labour markets and involuntary unemployment green tax reforms could, under certain conditions, generate both a higher level of employment and cleaner environment thus reaping a double dividend ${ }^{5}$.

The potential of revenue recycling is important, when taxes are compared with other policy instruments, such as emissions trading with free allocation of permits or regulatory

\footnotetext{
${ }^{2}$ This requires that the uncompensated wage elasticity of labour is positive, which is the case according to the most estimates found in economic literature.

${ }^{3}$ See Parry and Oates (1998).

${ }^{4}$ See e.g. Goulder (1995) and Bovenberg and Goulder (2001).

${ }^{5}$ For the discussion on the double dividend and employment effects, see Schoeb (2003).
} 
measures. As far as these instruments have a similar impact on consumer prices as taxes, they also have a similar tax-interaction effect. However, since they do no raise revenues, the positive revenue recycling effect is absent, and the total costs (assuming the same size of welfare benefit) are always higher than in the case of taxes.

Model-based simulations usually indicate that green tax reforms can improve employment and the quality of the environment at the same time, provided that the tax revenues are recycled in the form of reductions of the employers' social security contributions $^{6}$. The ex-post evidence for the EU countries, which have carried out environmental tax reforms, also indicates that green tax reforms can have favourable effects both from an economic and an environmental perspective ${ }^{7}$.

Green tax reforms could also be seen as part of wider tax reforms that aim at shifting the tax burden from labour to consumption and/or polluting taxes, while simultaneously broadening the tax base. Such reforms seem pertinent, in particular, in view of the recent developments in the Member States. The heavier taxation on labour appears indeed to have been a disincentive to the creation of additional jobs, especially low skilled jobs ${ }^{8}$.

The revenues raised through environmental taxation also could be used in other ways for the benefit of the environment, the economy or both. First, the governments could earmark part of tax revenues for specific environmental purposes, such as financing eco-efficiency or eco-innovation investments. Secondly, tax revenues could also be used to compensate the households and businesses, who suffer disproportionately from higher taxation.

\footnotetext{
${ }^{6}$ This was the case, for instance, in Kouvaritakis et al. (2005), in which a general equilibrium model (GEM-E3) was used for policy simulations and in Cambridge Econometrics (2008), which was based on a macroeconometric model of Keynesian inspiration (E3ME).

${ }^{7}$ The COMETR project, which investigated the effects of green tax reforms in Denmark, Germany, Finland, the Netherlands, Sweden and United Kingdom, found that all the countries had both a higher level of economic activity and a lower fuel use and greenhouse gas emissions than in the hypothetical counterfactual scenario in which the reform did not take place. Tax reforms were assumed revenue-neutral in all cases and the revenues from higher energy taxes were used mainly to reduce income taxes or the employers' and employees' social security contributions. This revenue recycling was the main cause of beneficial economic impacts in the study. For the results of the COMETR project, see the web-site: http://www2.dmu.dk/cometr/.

8 The positive effects of green tax reforms on employment might however differ across sectors. For example, the increase in the price of energy may boost the production of energy-efficient products, which could require hiring more high-skilled than low-skilled workers.
} 
Compensation could take the form of income tax reductions or tax credits targeted to those specific groups. Financing the tax credits for energy efficiency, which are discussed in more details below, would be a way to reduce the regressivity of energy taxation and enhance energy-efficiency at the same time.

In spite of these advantages, root taxes are not always the best instrument to address environmental problems. In some cases direct regulation would bring forth the desired environmental outcome more effectively. This is the case, in particular, when environmental damages are location-specific and vary with the source of pollution, and therefore more targeted instruments than general emissions taxes are required. On the other hand, quantitybased instruments, such as emission quotas, are often favoured on the ground they bring forth more certainty in reaching given environmental targets than price-based instruments, such as taxes. Combinations of taxes and other policy instruments may also turn out to be more effective than using taxes alone. The circumstances, in which this would be the case, are discussed more closely in chapter 3.

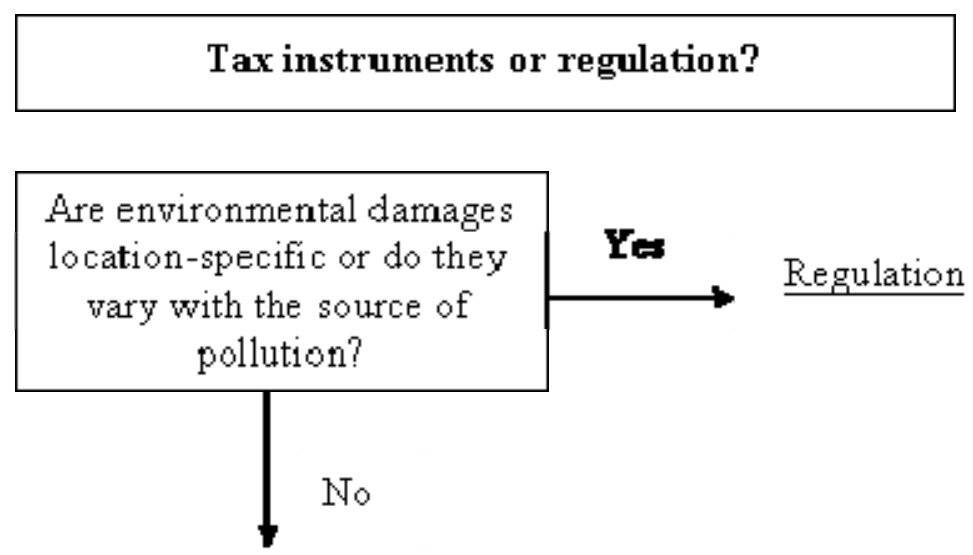

$\underline{\text { Root taxation }}$

\section{Box 1. Internalisation of external costs}

When a tax on emissions is set equal to the value marginal social damage caused by those emissions, it is said to fully internalize external costs. External costs arise, because environmental quality has the property of a public good, the provision of which is not ensured by the market mechanism. Taxes can be used to correct for this market failure. Such taxes called Pigouvian taxes - ensure that pollution is reduced to the level at which the marginal 
private benefit to the polluter is precisely equal to the marginal social costs (i.e. external costs) caused by the pollution. It corresponds to the "Polluter Pays Principle", as the polluter pays in the form of the tax the cost of pollution to the society. A tax that directly tackles the source of externality, i.e. emissions, is also called root taxation. Note also that in the presence of certainty, a cap-and-trade scheme on emissions is equivalent to an emission tax with respect to static and dynamic efficiency. Although the idea of Pigouvian taxes is appealing, it has also some caveats in both theoretical and practical sense.

Theoretical arguments point out that the optimality of the Pigouvian tax is based on the partial equilibrium analysis and does not take into account the pre-existing distorting taxes (i.e. the fact the governments cannot in practice finance public spending through lump-sum taxes). In the second-best setting, in which distorting taxes are present, the optimal level of a pollution tax is not equal to the Pigouvian tax, but is generally lower. Bovenberg- Goulder (1996) show that in this setting the optimal tax is equal to the marginal environmental damage (MED) divided by the marginal cost of public funds. As the latter is above unity in the presence of distorting taxes, the optimal tax is below the Pigouvian level (equal to MED) approximately by $80-90 \%$, in the case the tax revenues are used to reduce marginal income tax rates (see, also Parry and Oates,1998).

West and Williams (2004) argue, however, that the above analysis is based on the assumption of the weak separability between leisure and consumption in household utility, and show that the tax rate on goods, which are complements to leisure, such as gasoline, should optimally be above the Pigouvian level, because in such the tax (by increasing the price of the good) would increase the labour supply. They estimate empirically the cross-price elasticity between gasoline and leisure, and conclude on that basis that the tax on gasoline should optimally be 35\% above the MED.

Other arguments against the Pigouvian tax are of more practical nature. The value of MED is generally not known and also notoriously difficult to estimate because of the complex and intertemporal nature of many environmental problems. Baumol and Oates (1988) suggest, instead, an approach, which let the environmental targets (e.g. in terms of the amount of emissions reduction) to be determined by the political process (instead of optimising) and set the tax in such a way to reach the pre-determined target at a minimum cost. Such a tax would be cost-effective, as it would equate marginal abatement costs across potential options and actors of abatement, and thus ensure the efficient allocation of abatement effort in the economy, as well as to provide long-term incentives to pollution reduction through technological improvements.

\subsection{Distributional and competitiveness effects of environmental taxes}

The adverse effects of environmental taxes on the income distribution between the households and on the international competitiveness of firms are usually considered to be main obstacles to setting taxes at the environmentally effective level.

(a) Environmentally-related taxes are often levied on goods deemed of basic necessity (e.g. energy or transport), in particular when the objective to raise revenues is important. Taxing such goods may put a disproportionate burden on low-income households who spend 
more on these goods in relative terms (i.e. as a share of household income) than high-income households. Empirical evidence indicates that taxes on electricity and heating may indeed have a regressive impact, as low-income households generally spend a larger share of their total spending on these items than high-income households. Transport taxes, in contrast would burden relatively more higher-income than lower income groups. As a result of these two counteracting effects the distributional impact of energy taxation as a whole tends to be moderately regressive. The distributional impacts of pollution taxes are however generally found to be neutral ${ }^{9}$.

The recycling of tax revenues through the reductions of income taxes or social security contributions would, however, considerably mitigate the regressive impact of energy taxation, and completely reverse it, if the tax cuts boost employment sufficiently to increase the disposable income of the households at the low end of the income scale ${ }^{10}$. Using targeted tax credits or subsidies in combination with taxes are also an effective approach to compensate the low-income households for the impact of higher energy taxes. Regulatory instruments, which would merely impose higher standards on heating equipments, but would not generate revenues, would not offer the same possibility to compensatory measures.

(b) International competitiveness may be adversely affected, when a country unilaterally sets taxes on industrial inputs, in particular on energy. This increase of production costs could put local firms in a competitive disadvantage, with, as possible consequences, firms relocating to other regions or losing market shares to foreign competitors. The sectors that are particularly vulnerable in this respect are the ones with high energy-intensity, a large share of internationally-traded products and a low capacity to pass through cost increases to market prices. If the production moves permanently away from the region applying the strict

\footnotetext{
${ }^{9}$ See, EEA Report (2006) and Copenhagen Economics (2008).

${ }^{10}$ This was the case in the study carried out by Cambridge Econometrics (2008) for the Impact Assessment of the Revision of Energy Tax Directive. In the study the revenue recycling is assumed to go through the reductions of the employers' social security contributions, which have a strong effect on employment and household disposable income, since the model used in the study (E3ME) allows involuntary unemployment in labour markets even in the long-run.
} 
environmental policy, the reduction of emissions would be offset by an increase in other regions and global emissions would be barely affected. In the case of energy and carbon taxation, the phenomenon is referred to as "carbon leakage". However, existing empirical evidence does not give so far strong support to any major negative competitiveness effects of environmental tax reforms or carbon leakage ${ }^{11}$. This is not surprising as such, since all the countries that have carried out more ambitious green tax reforms, have also taken measures to protect their most vulnerable industries from the losses of competitiveness, for instance, by exempting these sectors partly or totally from these taxes. In addition, revenue recycling, which reduces indirect labour costs for the employers, helps to mitigate the adverse competiveness effects of environmental taxation.

\section{COMPLEMENTING TAXES WITH OTHER FISCAL INSTRUMENTS}

There are two basic reasons why tax instruments alone may be insufficient to tackle environmental problems and need to be complemented with other policy instruments.

First, due to information costs and asymmetries emission, taxes, which ensure the optimal outcome in the first-best world (see box 1), may be difficult to implement in practice. Emissions are not observed at the market place, and their measurement and monitoring may be prohibitively costly or technically unfeasible ${ }^{12}$. It may also be administratively cheaper to use the existing tax system to address environmental problems, for instance by the differentiation of the tax rates in indirect taxation, than to introduce entirely new taxes. Therefore, taxes are often based on the sales of goods that are related to the externality rather than on the externality itself. As the tax bases of such instruments are imperfect proxies for the externality, they correct for the externality in an inefficient way compared to first-best

\footnotetext{
${ }^{11}$ This was also suggested by the results of The COMETR project.

12 Emission taxes are feasible, however, for carbon emissions, since the carbon content of fossil fuels purchased in the market place can be rather accurately measured, and for certain other emissions, which are continuously monitored due to regulatory requirements (NOx and SO2 of big power plants).
} 
instruments ${ }^{13}$. The inefficiency arises from the fact that the behavioural response to such a tax is inadequate; it induces consumers to reduce the consumption of the good in question, but not to cut emissions. For example, an output tax on electricity provides an incentive to reduce electricity consumption but not to reduce the carbon emissions in electricity generation.

On these grounds some authors suggest the use of multi-part instruments, i.e. the combinations of indirect taxes with other fiscal instruments (subsidies), which could better target emissions or other externalities than a single tax instrument. For example, an instrument that replaces an emission tax on cars would be efficient as such, but may not be considered feasible because of difficulties in measuring car emissions. Fullerton and West (2002) show that an equally efficient outcome could be achieved by a combination of gasoline tax, a flat rate tax on engine size and a flat rate subsidy to pollution control equipment ${ }^{14}$. Fullerton and Wolverton (2005) consider a combination of an output tax and a subsidy for clean alternatives to pollution as a generalisation of a deposit-refund system and examine, how such two-part instrument should be designed in the second-best setting, in which the government has a revenue-raising requirement but cannot use lump-sum taxes in order to achieve the same incentive effects as a direct tax on pollution.

The second justification for using the combination of instruments in environmental policies is the presence of market imperfections or market failures other than the environmental externality. Under such condition, a single tax instrument might be inefficient or its use may involve much higher costs than the combination of two or more instruments, even if an efficient first-best instrument were available. Complementary instruments can be of diverse nature, ranging from information campaign, labelling and direct subsidies to differentiated indirect tax rates in favour of clean products. The market failures may arise for various reasons.

\footnotetext{
${ }^{13}$ Such taxes are often labelled imperfect externality-correcting taxes in economic literature (see, Christiansen and Smith, 2008)

${ }^{14}$ This result holds in the case of homogeneous consumers. However, in the case of heterogeneous consumers, the flat rates would not achieve first best but would still be second-best optimal.
} 
First, consumers do not always have adequate information on the qualities of products (e.g. energy-saving capacity) and their relationship to environmental problems. In such cases, information tools, such as labelling schemes, can usefully complement tax instruments. Subsidy schemes may also serve to raise awareness and provide more information on product qualities, but are likely to be less cost-effective. Second, credit market constraints may make it difficult to finance through borrowing the purchases of the products, which are relatively expensive for ordinary households, such as energy-efficient cars, household appliances or heating equipment. Direct subsidies, tax credits or allowances could in such a case serve to alleviate this affordability problem and usefully complement tax instruments.

A third case relates to the principal-agent problem that may weaken the incentives provided by taxes to invest in energy-efficient building materials and equipment. The problem arises because the builder or the owner of the house is not necessarily the one that pays the energy bill (the tenant). In such a situation, a tax credit or other subsidy to the owner may enhance the sales of more energy-efficient equipments. Fourth, consumers may also be myopic in the sense that they disregard or undervaluate the distant benefits of future energy savings and pay more attention to up-front costs ${ }^{15}$. In such a case, fiscal instruments (which reduce purchasing costs) are more effective than the tax increases (which affect the energy bill over the product life time). A lack of information may also be a cause of such undervaluation, in which case information tools should be used to complement taxation.

There can also be cases for which the absolute size of energy saving per unit purchase is small, especially compared to search costs. In such cases, consumers might not bother looking for more energy-efficient products because they perceive this marginal cost as too high compared to the marginal benefit of energy savings. In such a situation too a tax credit or other subsidy may enhance the sales of more energy-efficient equipments. Six, multiple externalities are important, in particular, in the case of R\&D activity, which is known to entail

\footnotetext{
${ }^{15}$ Or in other words, the consumers in such cases apply discount rates significantly above the social discount rates to future benefits (see Goulder and Parry, 2008)
} 
a significant positive externality in the sense that the social return exceeds private benefit by a significant amount. Market-based instruments do provide incentives to innovations in clean technologies, but a single instrument, even the first-best emissions tax, is likely to be insufficient or very costly to tackle the two externalities at the same time ${ }^{16}$. The instruments that could complement first-best instruments in such cases include direct subsidies or fiscal incentives to $R \& D$, but could also include other kinds of measures targeted to promote clean technologies. Finally, complementary instruments make economic sense if they can help moving away the activity from the household sector ("do-it-yourself") and black market to the official production sector. This is the so-called Productivity Argument described below in this paper.

It should be kept in mind, however, that the use of complementary instruments, in particular fiscal instrument, is not without caveats, and should be in each case carefully designed and evaluated. First, all subsidies - given either directly or through the tax system cost money to governments. They have to be financed either by increasing other taxes or reducing public expenditure, which will entail welfare costs. Moreover, administrative costs of subsidy/incentive schemes may also be high compared with increasing existing taxes. Therefore the benefits achieved through the use of tax incentives (in the form of energy saving or lower emissions) should always be compared to the costs before implementing such measures. An example of the assessment of the costs and benefits of fiscal incentives combined with taxes is presented in chapter (5). Secondly, fiscal incentives may not be effective, even disregarding the costs. There are number of reasons for this. First, all fiscal incentives are not necessarily passed through to consumer prices, at least in the short-term ${ }^{17}$, in which case they would not have the desired effect on consumer behaviour. Second, the effectiveness of incentive schemes may be reduced by the rebound effect and free-rider

\footnotetext{
${ }^{16}$ See Goulder and Parry (2008) for an overview of the literature where the argument is presented.

${ }^{17}$ Copenhagen Economics (2007) reports evidence however that VAT changes are almost fully passed through to final prices in the long-term.
} 
problems. The rebound effect implies that lower prices of appliance would induce the consumers to purchase more of them, or use them more intensively, which would eventually lead to higher energy consumption ${ }^{18}$. The free-rider problem means that subsidies are given to consumers who would have bought the energy-efficient appliance in any case.

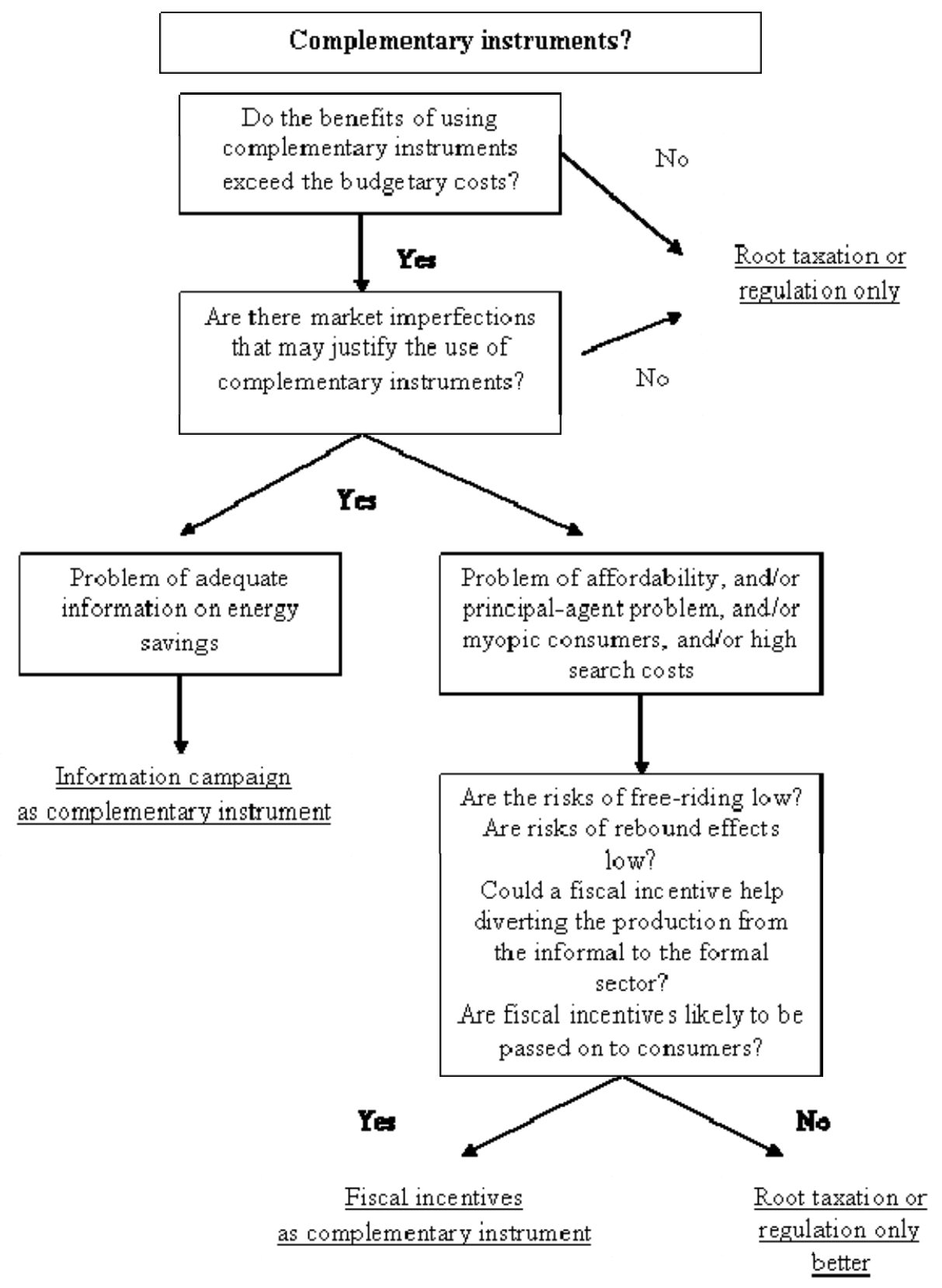

\footnotetext{
${ }^{18}$ Empirical evidence on the rebound effect is rather scarce. UKERC (2007) report provides a comprehensive overview of the existing evidence and concludes that the direct rebound effect is likely to be less than $30 \%$ for household heating, cooling and personal automotive transport, and closer to $10 \%$ for transport. However, if indirect effects are also taken into account, the economy-wide rebound effect could be larger and thus the energy saving achieved much lower than expected.
} 


\section{REDUCED VAT RATES ON THE SUPPLY OF ENERGY-EFFICIENT GOODS AND SERVICES}

a. Provisions under the VAT Directive.

The current VAT system in the EU is organised by the Council VAT Directive 2006/112/EC. Under the basic provision of this Directive, Member States have to subject the supplies of goods and services to a standard rate of at least $15 \%$. Next to this general provision, Member States have the possibility to apply one or two reduced rates - of no less than 5\% - to a list of supplies of goods and services included in the Annex III to theVAT Directive $^{19}$. Further, Article 102 of the VAT Directive provides that "Member States may apply a reduced rate to the supply of natural gas, of electricity or of district heating, provided that no risk of distortion of competition thereby arises". Article 122 of the VAT Directive provides that "Member States may apply a reduced rate to the supply [...] of wood for use as firewood." Moreover, Title VIII, Chapters 4 and 5 of the VAT Directive include special or temporary provisions on energy products.

\section{b. Uniformity or differentiation: general issues.}

An important policy question is whether the VAT system shall be uniform with a single rate for all products and services, or whether one shall allow for rates differentiation and have the option to apply reduced rates.

The traditional view ${ }^{20}$ follows Ramsey (1927) and states that optimal (in the efficiency sense) VAT rates shall ensure that the tax scheme reduces the consumption of each and any good in the same proportion. Since the demand of each good depends on the price of the other (substitute or complement) goods in different ways, this would call for a complex system of multiple VAT rates. Unfortunately, to design such a scheme, policy-makers should observe

\footnotetext{
${ }^{19}$ In addition, the Directive foresees VAT derogations for some Member States and sectors, temporary provisions for particular labour-intensive services.

${ }^{20}$ See Heady (1993) for an excellent discussion.
} 
the cross-price elasticities between products but those are difficult to identify ${ }^{21}$. Another finding with policy implications comes from Corlett and Hague (1953) who showed that efficiency can be increased by taxing more heavily goods that are complementary to leisure ${ }^{22}$. A "Corlett-Hague tax" is a tax that does precisely this. Unfortunately, here again, the design of such VAT system rests on unobservable price elasticities between the goods and leisure.

These practical difficulties to design an optimal differentiated VAT system had convinced economists that the best practical policy may be to act as if all goods were all equally substitutable and complementary to leisure and tend to uniform VAT taxation. This view is also reinforced by several other considerations:

(a) The economic literature, in particular Atkinson and Stiglitz (1976) indicates that a non-linear (i.e. progressive) income tax is more optimal for redistribution purposes than differentiated commodity tax rates. In other words, using the progressivity of personal income tax systems is a better redistributive instrument than reduced VAT rates on products more heavily consumed by low-income citizens. Copenhagen Economics (2007) shows that certain goods are actually more extensively consumed by low-income groups only when countries have a high initial inequality and that the redistribution argument does not find sound empirical support as the demand for many of these goods is relatively inelastic (i.e. quantities demanded are relatively insensitive to changes in prices) so that a lower rate therefore benefit high-income individuals much more in absolute terms. In addition, Diamond and Mirrlees (1971) have shown that optimal taxation should also take into account income elasticity (i.e. how consumption of a good changes as income changes). Indeed, the simple inverse-elasticity rule could recommend that goods of basic necessity (whose demand is price inelastic) shall be taxed more heavily, although they are primarily consumed by lower-income classes.

\footnotetext{
${ }^{21}$ Under the additional assumption that demand for one good is independent of the prices of other goods, Ramsey (1927) could derive the 'inverse elasticity rule' that states that goods whose consumption is the less elastic shall be taxed more heavily. This rule is said to be a rationale for high taxes on tobacco or alcohol.

${ }^{22}$ In addition, Heady (1987) shows that price inelasticity and complementarity to leisure actually target the same goods.
} 
(b) Uniform VAT is easier to administrate and less prone to both fraud (by re-labelling goods $^{23}$ ) and lobbyism (by trying to obtain reduced rates for specific products). The economic effects of distortions and compliance costs associated with reduced VAT rates should not be underestimated as empirical evidence indicates that compliance costs associated with lower VAT rates can be sizeable. Differences in VAT rates between similar products may in particular give rise to sizeable costs for businesses and tax authorities to administrate reduced rates and to a substantial number of administrative and legal conflicts about the proper classification of specific goods.

(c) The use of reduced VAT rates to promote employment or to promote merit goods (i.e. goods that are deemed desirable such as books, culture, etc) do not find strong empirical evidence (see Copenhagen Economics, 2007). For employment purposes, the argument is that reduced VAT rates on labour-intensive sectors would boost demand for those services and thereby stimulate demand for low-skilled workers and push up their wages, making employment more attractive. A condition for this to work is a non-functioning labour market for low-skilled workers. Although there may be some positive effects in the short-term, the long-term impact appears low or nonexistent unless the reduced rates are well-targeted. One reason is that differences across sectors in low-skilled employment are limited.

For the promotion of merit goods, the basic idea may clash with the redistribution concerns as many of these goods are primarily consumed by high-income categories. The argument of redistribution only finds empirical support in countries with high initial income inequality.

(d) Finally, Uniform VAT is more stable. This is because unlike a system of differentiated rates based on cross-price elasticities, there is no need to change the relative rates when tastes or technologies are changing.

\footnotetext{
${ }^{23}$ One example relates to the so-called "mixed supply". This is the case when a good taxed at a reduced VAT rate is supplied and this service is taxed at the standard rate. Both the supplier and the consumer have an incentive to artificially increase the share of the good in the total bill.
} 
Recent research by Kleven (2004) and discussed in Sorensen (2006) puts however new light on this debate. Kleven's model departs from the traditional goods-services market production by including a third sector: the household production of services. These concern activities that can be carried out - but not registered as such - by households such as house cleaning, baby care, car-washing, do-it-yourself activities, etc. Kleven (2004) shows that a high tax on these activities, which are complement to leisure, are not an efficient way to stimulate labour supply. This is because they will tend to encourage substitution of home production with market production. His 'inverse-factor share rule' recommends to put a low tax rate on activities that can be produced in both the household sector and the market sector. This policy is a revised form of Ramsey taxation. In addition, it provides two interesting features: (a) it can be shown that, unlike uniform VAT and Corlett-Hague taxes, the solution is a first-best allocation in the sense that it acts like a non-distortionary tax, and (b) unlike Corlett-Hague taxes, they depend on observable factors (the degree to which they can be done by households) and not on unobservable price elasticities. The argument is that a reduced VAT rate on locally-supplied services whose consumption reduces or saves household time could avoid the diversion of activities that could be produced in the market by activities produced in the household sector. For example, a low VAT rate on cleaning of private dwelling could avoid do-it-yourself activities and would increase global productivity. This is because hours spent by household on those activities could be spent instead on their job (or leisure) and professionals could take care of these locally-supplied activities. This paper refers to it as the 'productivity argument'. Copenhagen Economics (2007) finds strong economic evidence of this effect, the more so the higher the standard VAT rates.

\section{c. Uniformity of differentiation: the case of energy-efficient goods and services.}

Some Member States have repeatedly asked for the possibility to apply reduced rates to the supply of environmentally friendly, energy saving and energy efficient goods. Consequently, there was a need to assess the usefulness of the tool of reduced VAT rates to 
promote the use of environmentally friendly goods. At the same time, coherence prompts to include in the assessment the question whether current applications of reduced rates to goods and services relating to environmentally damaging behaviour should not be abolished.

Copenhagen Economics (2008) recommends moving away from reduced VAT rates on energy. This is because it is in sharp conflict with environmental policies as removing these rates would decrease EU final energy consumption and the income distribution consequences are marginal and can be dealt with more efficient tools such as direct income support $^{24}$. In addition, there is a macroeconomic argument for moving away from reduced VAT rates on energy as taxing energy also helps improving the terms-of-trade of the European Union and reduces wealth transfer to oil-exporting countries. Finally, the use of reduced VAT should be considered in relation to other policy tools, such as the Emissions Trading System (ETS). Indeed, a large share of the energy sector is already covered by the cap-and-trade system of the ETS (in this context, a large share of electricity consumption and district heating). So, encouraging lower use of energy on the product consuming energy covered by the ETS would simply lead to a lower price of ETS emission allowances, while leaving the total level of $\mathrm{CO} 2$ unchanged. It amounts to redistribution in the price of permits. Reduced VAT rates applied to a large range of energy consuming household goods for promoting energy-efficiency appear to bring little value-added to the existing ETS system, entail compliance costs both for businesses and tax authorities and pose a serious risk of cross-border shopping if reduced rates are optional for Member States (even though this risk is limited to a number of products and the effects shall not be overestimated as prices of energy-using products already show significant differences across countries ${ }^{25}$ ).

\footnotetext{
${ }^{24}$ The incidence of VAT increase is largest on the lowest income quintiles but the absolute size of the effects is small. If the additional revenues are recycled by way of a reduced VAT standard rate, the net increase in the consumption costs of the lowest quintile is 0.04 percent.

${ }^{25}$ The IVM (2008) report on differentiated VAT rates concludes that cross-border shopping for green goods would not seem to create problems.
} 
The first best-policy would therefore be to apply the standard VAT rate on energy as this would address the environmental problem and fit with efficiency concerns, while not posing problems related to redistribution. 10 Member States currently apply reduced rates for supply of domestic energy. In 2004, these subsidies amounted to $€ 7.3$ bn for the EU-15. Table (1) shows these costs.

Table (1): Annual subsidy amounts implicit in VAT reductions for energy use in households in EU countries in 2004.

\begin{tabular}{|c|c|c|c|c|}
\hline Country & Product & VAT rate $(\%)$ & Standard VAT rate $(\%)$ & Subsidy (€million) \\
\hline Belgium & Solid fuels & 12 & 21 & 6.7 \\
\hline Estonia & Solid fuels & 5 & 18 & 0.5 \\
\hline Greece & Natural gas & 9 & 19 & 4.3 \\
\hline Greece & Electricity & 9 & 19 & 239.0 \\
\hline Hungary & Solid fuels & 15 & 20 & 1.2 \\
\hline Ireland & Solid fuels & 13.5 & 21 & 11.5 \\
\hline Ireland & Fuel oil & 13.5 & 21 & 30.6 \\
\hline Ireland & Natural gas & 13.5 & 21 & 52.9 \\
\hline Ireland & Electricity & 13.5 & 21 & 152.1 \\
\hline Italy & Solid fuels & 10 & 20 & 0.3 \\
\hline Italy & Natural gas & 10 & 20 & 114.2 \\
\hline Italy & Electricity & 10 & 20 & 1532.9 \\
\hline Luxembourg & Solid fuels & 12 & 15 & 0.0 \\
\hline Luxembourg & Fuel oil & 12 & 15 & 2.7 \\
\hline Luxembourg & Natural gas & 6 & 15 & 12.5 \\
\hline Luxembourg & Electricity & 6 & 15 & 25.9 \\
\hline Malta & Electricity & 5 & 18 & 10.5 \\
\hline Portugal & Fuel oil & 12 & 21 & 26.5 \\
\hline Portugal & Natural gas & 5 & 21 & 39.0 \\
\hline Portugal & Electricity & 5 & 21 & 556.7 \\
\hline United Kingdom & Solid fuels & 5 & 17.5 & 45.3 \\
\hline United Kingdom & Fuel oil & 5 & 17.5 & 54.4 \\
\hline United Kingdom & Natural gas & 5 & 17.5 & 1907.8 \\
\hline United Kingdom & Electricity & 5 & 17.5 & 2491.6 \\
\hline TOTAL EU-15 & Solid fuels & & & 65.6 \\
\hline TOTAL EU-15 & Fuel oil & & & 114.1 \\
\hline
\end{tabular}




\begin{tabular}{|c|c|l|l|c|}
\hline TOTAL EU-15 & Natural gas & & & 2130.7 \\
\hline TOTAL EU-15 & Electricity & & & 5008.7 \\
\hline TOTAL EU-15 & TOTAL & & & 7319.0 \\
\hline
\end{tabular}

Source: IEEP et al., 2007 copied from IVM (2008)

If the standard VAT rate was applied to domestic energy in these countries, it is estimated that domestic gas consumption would fall by $4 \%$ and domestic electricity consumption by $3 \%$, a great contribution to the EU's energy goals. Raising taxes on energy would however be difficult for the time being ${ }^{26}$. Hence, one needs to look at the alternative option of using reduced-VAT rates on energy-efficient or environmentally-friendly products.

Copenhagen Economics (2008) also reviews this option. More specifically, their study looks at the mandatory or voluntary application of reduced VAT rates on energy-efficient household appliances using electricity or producing heat (second scenario). Implementing a mandatory or voluntary reduced VAT rate of $12 \%$ or $5 \%$ on efficient products (energy class A or better products ${ }^{27}$, which represent more than $80 \%$ of the market in some member States) would also result in lower energy consumption and negligible redistributive effects. However, within the assumptions of the study ${ }^{28}$, the results suggest that electricity consumption (due to reduced rates on energy efficient electricity consuming household appliances and consumer electronics) could go up. Indeed, the study shows that lower VAT on energy-efficient products of class A or above make consumers buy additional appliances, or replace their current appliance with a larger one (hence consuming more energy) or be less 'cost-aware' when it comes to energy consumption. All of which could reduce the effectiveness of the policy. The effect of overall decrease of energy consumption in the

\footnotetext{
${ }^{26}$ At the same time, the economic crisis calls for long-term policies to reduce energy consumption. It has also been possible in the past to remove or phase out reduced VAT rates for energy products as this was the case in Austria (1983), Belgium (1980-1983), Czech Republic (1994-1997), Greece (1992), Hungary (2003-2005), Italy (1984-1988), Poland (1998), Portugal (1996) and Slovak republic (2003).

27 The energy efficiency of numerous products is addressed in several directives through minimum energy requirements and labelling setting classes of efficiency (see for example Directive 92/42/EEC on efficiency requirements for new hot-water boilers fired with liquid or gaseous fuels, Energy label Directive 2002/31/EC, or Directive 98/11/EC on energy labelling of household lamps).

${ }^{28}$ The sensitivity analysis offered by the report shows that this rebound effect is sensitive to the assumed substitution elasticity between energy efficient and conventional variants of the products considered.
} 
second scenario is to be attributed to the reduction of VAT on heating boilers. However, in countries where most products already are of an energy efficient variant, household consumption of electricity could go up instead of down (resulting in the so-called 'rebound effect'). This effect seems however to be drastically reduced when the use of reduced VAT rates is limited to class $\mathrm{A}+$ of above products. A conclusion is that any subsidy scheme would thus need to be well designed to achieve a decrease of energy consumption and reflect national circumstances and adapted to the characteristics of the product (the price premium for the energy efficient variant and later energy savings differ across product groups), which undermines the logic of the mandatory use of reduced rates in the EU. Moreover, the report highlights that additional taxation measures such as in the second scenario only make sense if they bring value-added because of some market failures that prevent consumers to get the right signal (as discussed in chapter 3) and if these market failures cannot be better corrected with direct subsidies (see discussion below). In addition, reduced VAT rates for energyefficient products entail administrative costs (for example, the possibility of mixed supply issues $^{29}$ ) and problems of standardisation and classification of products that could benefit from these reduced rates and, because the penetration of these products varies largely across countries, the effects of introducing additional measures would differ across countries. Finally, there is a risk of cross-border shopping as many of these products are highly tradable.

In terms of budgetary impacts, Copenhagen Economics (2008) estimates that removing reduced VAT rates on energy consumption would lead to an increase in VAT collection of about EUR 3.4 billion (or $0.03 \%$ of GDP) for the EU-27, that is an increase by 0.64\%. Alternatively, applying a mandatory reduced VAT rate at 5\% on energy-efficient products with label "A" (representing more than $80 \%$ of the market in some Member States) would generate a loss in VAT collection equivalent to $0.1 \%$ of GDP, which is a decrease in VAT collection by $1.5 \%$. Copenhagen Economics (2008) provides a sensitivity analysis for

\footnotetext{
${ }^{29}$ This is the case of a good that is taxed at a reduced VAT rate and is linked to a service taxed at the standard rate or the opposite.
} 
the Netherlands and Spain. These two countries have a market share of energy-efficient products respectively amongst the highest in the EU and just below the EU average. The analysis shows that restricting the use of reduced VAT rates to products with labels $\mathrm{A}+$ or superior instead of A and superior, leads to a decrease in the loss of VAT receipts from $0.6 \%$ to $0.1 \%$ and $0.4 \%$ to $0.0 \%$ respectively, therefore reducing the budgetary impact.

\section{DIRECT FISCAL INCENTIVES TO PROMOTE ENERGY-EFFICIENCY}

This chapter deals with subsidies paid directly in cash or given through the tax system in the form of tax credits, allowances or exemptions to the consumers and producers of environmental-friendly products. The focus is, in particular, on the products, where the energy-saving potential is substantial, namely the energy-efficient categories of lighting and heating equipment and electric household appliances.

\section{a. Examples of direct fiscal incentives used in the EU and non-EU countries}

Direct fiscal incentives for these purposes are, or have been, used in a number of EU Member States. In most cases they take the form of a subsidy or rebate provided after the purchase (The Netherlands) or paid directly at the check-out (Spain, Hungary, Denmark), in some cases delivered only in case of replacement of the old appliance (Spain, Hungary). In Italy the consumers receive a tax credit for the purchases of energy-efficient $(\mathrm{A}+$ and $\mathrm{A}++)$ refrigerators and freezers (delivered only in case of the replacement of the old appliance). The purchases of condensing boilers are promoted in France through a tax credit and Austria through region-specific subsidy schemes. There are also a wide range of programmes, including various subsidy schemes, promoting the purchases of compact fluorescent lamps (CFLi) in EU and non-EU countries.

In the US, subsidies and tax incentives are used more commonly than in the EU to promote energy-efficiency. Unlike in the EU, tax incentives are often given in the form of 
corporate tax credits to the manufacturers of energy-efficient appliances, or the owners of commercial buildings for the installation of energy-efficient equipment. Many US states also provide subsidies and personal income tax credits for energy conservation investments ${ }^{30}$.

\section{b. The costs and benefits of direct fiscal incentives}

The costs and benefits of direct fiscal incentives have been assessed in a study carried out for DG TAXUD in $2008^{31}$. This is done for four different products (refrigerators, washing machines, boilers and CFLi), and for four different EU Member States (France, Denmark, Italy, Poland) $)^{32}$

Three types of fiscal incentives are examined: subsidy for consumers, tax credit for manufacturers and tax credit for consumers. These policies are compared in each case to an alternative policy measure. In six cases it is the increase of energy tax (leading to $10 \%$ increase of energy prices) and in two cases the regulatory measure of removing the appliance with lower energy-efficiency labels from the market. These policy options are compared to the baseline scenario in which the energy prices are increased by $12 \%$ for the current situation, capturing the effect of the EU ETS on electricity prices. This was done in order to assess what additional benefits would direct fiscal incentives entail, when policies affecting energy prices are already in place.

The costs and benefits of policies were assessed with a help of an economic model of consumer behaviour, which assumes that the consumer always selects the appliance category with best net present value. The benefit consists of the monetary value the reductions of GHG emissions achieved through energy savings resulting from the shifts to more energy-efficient categories of products. The costs are the sum of welfare and administrative costs and were calculated in the following way:

\footnotetext{
${ }^{30}$ See, for more details (BIO Intelligence Service (2008).

${ }^{31}$ Bio Intelligence Service (2008).

32 i.e. altogether eight case studies.
} 
(1) In the case of subsidies and tax credits welfare costs arise because of the necessity to raise taxes to finance them. The size of the costs is assumed to be $26 \%$ of the amount of revenue raised. On the other hand, there are also welfare gains form two different sources: (a) gains to the producers from the extra sales of more efficient equipment (assumed to be 68.5\% of profits depending on the product) and (b) gains from the reductions of the emissions of non-GHG pollutants from energy generation (which have a negative impact on air quality and health). These gains are deducted from the welfare costs to obtain net welfare costs. Total costs are obtained by adding administrative costs to net welfare costs. Administrative costs they are assumed to be $5 \%$ of the revenue cost of the subsidy, and zero for tax credits.

(2) In the case of tax policies the deadweight loss associated with higher taxation is counted as a loss (representing the distorting impact of taxes on the economy), while the savings in costs from raising other taxes are counted as a gain (the revenue recycling effect). There is a second welfare cost arising from the fact that consumers are induced to buy more expensive equipment than they would if there were no tax. Welfare gains are calculated in the same was as in the case of subsidies and tax credits and deducted from welfare costs. Administrative costs are assumed to be $0.20 \%$ of the tax revenue.

(3) In case of removing the products of class B and below from the market (examined only for washing machines) the welfare cost arises from the fact that the consumers are induced to buy more expensive equipment, while the two welfare gains are calculated in the same way as in other cases and deducted from the welfare costs. Administrative costs are also assumed to be zero in this case.

The results of the cost-benefit analysis are summarized in tables (A1) and (A2) of the annex to this paper. The table shows the difference between the benefits resulting from energy saving and the associated reduction of $\mathrm{CO} 2$ emissions and total costs (net welfare costs plus administrative costs) for different policy options. The negative value indicates that the costs exceed the benefits and that the policy therefore is costly for the society as a whole. For the 
sake of comparison the table also shows and the amount energy savings (in GWh) generated by the policy during the life-time of the product in question.

On the basis of the results the following conclusions can be drawn: (1) In case of increases in energy taxes the benefits exceed the costs by a relatively wide margin and energy taxation thus appears to be a cost-effective way of improving energy-efficiency in the economy. (2) Subsidies have also a considerable potential in generating energy savings exceeding that of energy taxation substantially in some cases (compact fluorescent lamps (CFLi) in Poland and refrigerators in France and in Denmark). Tax credits for the consumers purchasing condensing boilers also turn out to have a high energy saving potential. In this respect there is, however, a considerable difference between Italy and Denmark for the reason that condensing boilers already constitute $80 \%$ of the market Denmark while their share is only $12 \%$ in Italy. The result indicates that the effectiveness of the policy depends very much on the market conditions prevailing in the country. Because of their effectiveness in generating energy savings direct subsidies and tax credits to consumers are in most cases costeffective policies in the sense that their benefits exceed the costs to the society. (3) In contrast, tax credits to manufacturers (washing-machines in Italy and Poland) are costly policies. The net welfare costs of the policy are relatively high and the energy saving potential relatively low compared with other instruments, leading to a negative benefit- cost balance. A regulatory measure (removing class $\mathrm{B}$ and lower form the market) was assessed as an alternative policy for tax credits in the case of washing machines (in Italy and Poland). This policy also turns out to have a relatively weak capacity to generate energy savings, although somewhat higher than that of tax credits to manufacturers in case of Poland. The benefit- cost balance of the policy thus turns out to be negative for the society as a whole. However, for individual consumers, savings due to the reduction of energy consumption are broadly equivalent to the increase cost of purchasing the equipment and the policy thus does not entail any extra costs to the consumers. 
It should be pointed out that the rebound effect, which in other studies is found to undermine the effectiveness of energy-efficiency polices, is not taken into account in this study and hence the energy saving potential of policy measures may be overestimated. This limitation should not affect, however, the comparison of policy options in terms of costeffectiveness $^{33}$.

The results indicate that subsidy policies can indeed usefully complement tax instruments in promoting energy efficiency and may entail much bigger benefits in this regard than tax increases in specific cases. However, as the results above indicate, this depends on the product and markets conditions and, in each case, these should be carefully investigated. The design of the instrument also matters: direct subsidies (paid in cash) and tax credits to consumers have by far lower overall costs relative to the benefit achieved than tax credits to manufacturers. Although subsidy policies tend to have higher welfare costs than tax policies, they certainly offer a feasible alternative to tax increases, in particular, when distributional and political concerns constrain the use of tax instruments.

\section{DIRECT FISCAL INCENTIVES IN COMPARISON WITH REDUCED VAT RATES}

Direct fiscal incentives address the same policy objective as reduced VAT rates assessed in the previous chapter and represent in this sense an alternative instrument ${ }^{34}$. They have a number of advantages compared to reduced VAT rates.

First, subsidy schemes can be better targeted to specific consumer groups, e.g. lowincome households. This helps to address distributional concerns of energy taxation. Targeting may also alleviate the free-rider problem, namely the fact that the benefit of a reduced VAT rate also goes to the consumers, who would purchase an energy-efficient

\footnotetext{
${ }^{33}$ For a more detailed explanation of the methodology applied in the study, results of the sensitivity analysis and the assessment of the limitations of the approach, see BIO Intelligence Service (2008) and a summary by DG TAXUD on the web-site: http://ec.europa.eu/taxation_customs/taxation/gen_info/economic_analysis/economic_studies/index_en.htm ${ }^{34}$ Note that the direct subsidy shall comply with State aid rules.
} 
appliance in any case. Hence the same target can be achieved more cost-effectively. In addition, direct fiscal incentives are likely to be more visible to consumers and thus may have a stronger signalling effect than reduced VAT rates. Second, contrary to direct tax incentives VAT reduced rates are not effective in the case of taxable economic agents which can deduct VAT paid on inputs. Third, direct fiscal incentives would not probably create the risk of distorting cross-border trade in the same way as reduced VAT rates, if they are targeted only to the residents of a country. Fourth, subsidies delivered at the check-out or as income tax credits to consumers are more certain to reach the consumer than reduced VAT, which may not be entirely passed through to retail prices. The same does not apply, however, to corporate tax credits given to the manufacturers. Fifth, direct subsidies can be more calibrated to the product characteristics: (a) some products need higher subsidies than others to motivate consumers. Reduced VAT may not sufficiently bridge the upfront price gap (which is the most relevant market failure for VAT to tackle) in case of large price difference between energy efficient and less efficient products and of (downward) price effects on the old stocks of less efficient products, (b) some products to be promoted also often have other better standards (of luxury) than the ones the specific policy wants to promote; and (c) the VAT instrument lacks flexibility in terms of tackling a possible rebound effect (e.g. it cannot be required that a purchase subject to a reduced rate concerns a replacement of an old appliance).

On the other hand, compared to reduced VAT rates, the creation of a subsidy scheme can be administratively more complex than the differentiation of rates in an existing tax regime (VAT) and thus may entail higher administrative costs. Finally, it must be taken into consideration that direct fiscal incentives, unlike reduced VAT rates, belong to the sole competence of the EU Member States and that therefore their use remains inevitably dispersed if the Member States do not coordinate their action in this regard. 


\section{Fiscal instrument: reduced VAT or direct subsidies?}

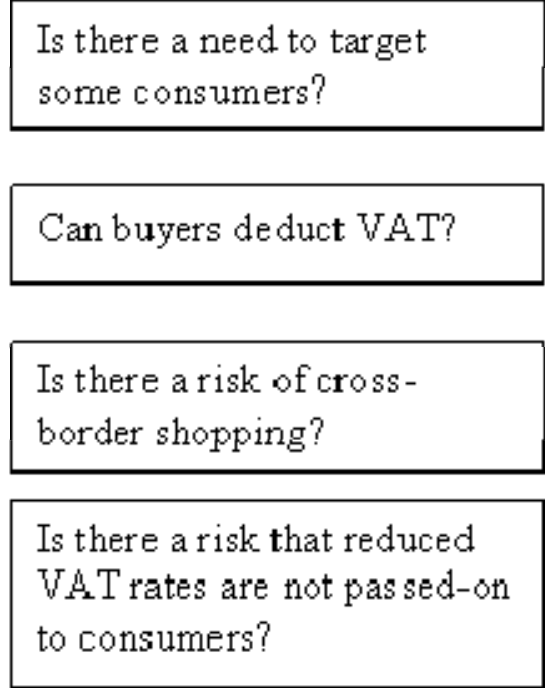

Is there a need to calibrate the instrument to the product's features?
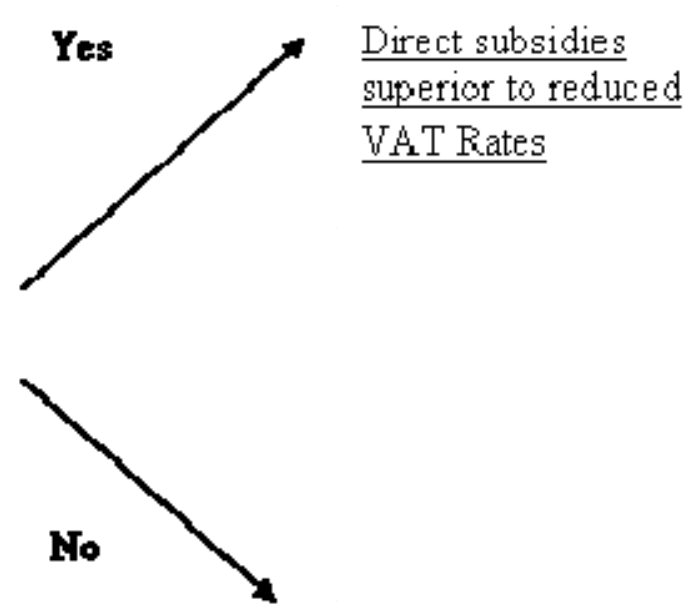

Direct subsidies or Reduced VAT Rates

\section{CONCLUSIONS}

Achieving the EU targets with respect to energy savings and reductions of greenhouse gas emissions requires coordinated efforts in a number of policy areas. Fiscal instruments can play an important role in reaching these goals, alone or in complement to other market based instruments and regulatory measures implemented in the EU. The advantage of fiscal instruments compared to regulatory instruments is often their efficiency and the fact that they can raise revenues that can be used to reduce distorting taxes elsewhere in the economy. Root taxation often proves to be superior to regulation when environmental damages are not location-specific and do not vary with the source of pollution.

However, tax instruments might sometimes be insufficient and need to be complemented by other fiscal instruments. Such complementarities are especially called for when there are information costs or market failures. In particular, affordability constraints for consumers, myopia about the long-term savings, high search costs, and principal-agent 
problems are typical situations which call for the use of complementary fiscal instruments, provided the risks of free-riding and of rebound effects are low, and these fiscal incentives are passed on to consumers. This complementarity may be achieved by differentiated commodity taxes or by direct subsidies, depending on the necessity to target specific consumers or product characteristics, as well as on the risks entailed by cross-border shopping on the single market. The opportunity to use such complementary instruments seems however to be rather limited in practice and root taxation remains in most cases the first-best option.

\section{References}

Atkinson, A.B. and Stiglitz, J.E. (1976). The Design of Tax Structure: Direct versus indirect taxation. Journal of Public Economics. 6:55-75.

Baumol, W.J. and Oates, W.E. (1988). The Theory of Environmental Taxation. Cambridge University Press (second edition).

BIO Intelligence Service (2008). A study on the costs and benefits associated with the use of tax incentives to promote the manufacturing of more and better energy-efficient appliances and equipment and the consumer purchasing of these products. Final report, December 2008.

Bovenberg, A.L. and de Mooij, R.A. (1994). Environmental Levies and Distortionary Taxation. The American Economic Review, vol. 94, no. 4, September 1994.

Bovenberg, A.L. and Goulder, L. H. (1996). Optimal Environmental Taxation in the Presence of Other Taxes: General-Equilibrium Analyses. The American Economic Review, vol. 86, no. 4, September 1996.

Bovenberg, A.L. and Goulder, L.H. (2001). Environmental Taxation and Regulation. NBER Working Paper, n 8458, September 2001.

Cambridge Econometrics (2008). Review Of the Energy Taxation Directive: Final modelling results. A report for DG TAXUD, European Commission, $18^{\text {th }}$ July 2008.

COMETR (2007). Competitiveness Effects of Environmental Tax Reforms. Final report to the European Commission, DG Research and DG Taxation and Customs Union, 2007.

Copenhagen Economics (2007). Study on reduced VAT applied to goods and services in the Member States of the European Union. Taxation Papers, $\mathrm{N}^{\circ} 13$.

Copenhagen Economics (2008). Reduced VAT for Environmentally Friendly Products. Final report, December 2008.

Corlett, W.J. and Hague, D.C. (1953). Complementarity and the Excess Burden of Taxation. Review of Economic Studies, 21:21-30.

Diamond, P.A. and Mirrlees, J.A. (1971). Optimal Taxation and Public Production: I and II. American Economic Review. 61: 8-27 and 261-278.

European Commission (1997). Environmental Taxes and Charges in the Single Market. Communication from the Commission. COM (97) 9 final.

European Commission (2007). Green Paper on market-based instruments for environment and related policy purposes (COM(2007)140 final). 
European Commission (2008). Proposal for a Council Directive amending Directive 2006/112/EC as regards reduced rates of value added tax, COM(2008)428.

European Council (2006). Council Directive 2006/112/EC of 28 November 2006 on the common system of value added tax. OJEU, L347, Vol. 49, 11 December 2006.

European Environmental Agency (2006). Using the market for cost-effective environmental policy. Market-based instruments in Europe. EEA Report no 1/2006.

European Environmental Agency (2007). Greenhouse gas emission trends and projections in Europe 2007. EEA Report 5/2007.

Fullerton, D. and Wolverton, A (2005). The two-part instruments in a second-best world. Journal of Public Economics 89, 1961 - 1975.

Fullerton, D., Leicester, A. and Smith, S. (2008). Environmental Taxes. The Institute for Fiscal Studies, March 2008.

Goulder, L. H. (1995): Environmental Taxation and the Double Dividend: A Reader's Guide.

International Tax and Public Finance, 2: 157-183.

Goulder, L. H. and Parry, I. W.H. (2008): Instrument Choice and Environmental Policy. Resources for the Future Discussion Paper 08-07.

Heady, C. (1987). A Diagrammatic Approach to Optimal Commodity Taxation. Public Finance. 42: 250-263.

Heady, C. (1993). Optimal Taxation as a Guide to Tax Policy: A Survey. Fiscal Studies, 14(1): 15-41.

IVM - Institute for Environmental Studies (2008). The use of differential VAT rates to promote changes in consumption and innovation.

Kleven, H.J. (2004). Optimal Taxation and the Allocation of Time. Journal of Public Economics. 88: 545-557.

Kouvaritakis, N., Stroblos, N., Paraousses, L., Revesz, T., Zalai, E. and van Regemorter, D. (2005). Impacts of energy taxation in the enlarged European Union, evaluation with GEM-E3 Europe. Study for the European Commission DG TAXUD, final report, July 2005.

Parry, I.W.H. (2003). Fiscal interactions and the case for carbon taxes over grandfathered carbon permits. Oxford Review of Economic Policy, vol. 19, no. 3, 2003.

Parry, I. W. H. and Oates, W. E. (1998): Policy Analysis in the Second-Best World.

Resources for the Future Discussions Paper 98-48.

Ramsey, F.P. (1927). A Contribution to the Theory of Taxation. Economic Journal, 37:47-61.

Schoeb, R. (2003). The Double Dividend Hypothesis of Environmental Taxes: A Survey. Fondazione Eni Enrico Mattei Working Paper no. 60, 2003.

Sorensen, P.B. (2007). The Theory of Optimal taxation: What is the Policy Relevance? International Tax and Public Finance, 14: 383-406.

UKERC (2007). The Rebound Effect: an assessment of the evidence for economy-wide energy savings form improved energy-efficiency. UK Energy Research Centre, October 2007.

West, S.E. and Williams III, R.C. (2004): Empirical estimates for environmental policymaking in the second-best setting. NBER Working Paper 10330. 


\section{APPENDIX}

Table A1: Results of the cost-benefit analysis for the eight case studies: policy option 1*

\begin{tabular}{|l|l|l|l|l|l|}
\hline \multicolumn{1}{|c|}{ Product } & \multicolumn{1}{|c|}{ Policy } & Country & $\begin{array}{l}\text { Net welfare } \\
\text { cost/tCO2 } \\
€\end{array}$ & $\begin{array}{l}\text { Benefits - costs } \\
€\end{array}$ & \multicolumn{1}{|c|}{$\begin{array}{c}\text { Energy } \\
\text { savings } \\
\text { (GWh) }\end{array}$} \\
\hline Refrigerator & $\begin{array}{l}\text { Subsidy for } \\
\text { consumers (€50 } \\
\text { class A+ only) }\end{array}$ & $\begin{array}{l}\text { France } \\
\text { Denmark }\end{array}$ & $\begin{array}{l}60,27 \\
-0,41\end{array}$ & $\begin{array}{l}-8978,3 \\
288,4\end{array}$ & $\begin{array}{l}1433 \\
114\end{array}$ \\
\hline $\begin{array}{l}\text { Washing } \\
\text { machine }\end{array}$ & $\begin{array}{l}\text { Tax credit for } \\
\text { manufacturers } \\
(€ 100 / \text { appl. A+) }\end{array}$ & $\begin{array}{l}\text { Italy } \\
\text { Poland }\end{array}$ & $\begin{array}{l}650,3 \\
283,9\end{array}$ & -18558636 & 59 \\
\hline Boiler & $\begin{array}{l}\text { Tax credit for } \\
\text { consumers (25\% } \\
\text { of appl. Price } \\
\text { deducted form } \\
\text { income tax })\end{array}$ & Denmark & $-23,9$ & 4565,2 & 18 \\
\hline CFLi & $\begin{array}{l}\text { Subsidy for } \\
\text { consumers (€1 } \\
\text { classes A and B) }\end{array}$ & $\begin{array}{l}\text { Poland } \\
\text { France }\end{array}$ & $-14,2$ & 692476292 & 40293,6 \\
\hline
\end{tabular}

*) Policy 1 is applied on top of baseline scenario (12\% increase of electricity price (refrigerators, washing machines, CFLi)/ $15 \%$ increase of gas price (boilers))

Table A2: Results of the cost-benefit analysis for the eight case studies: Policy option 2*

\begin{tabular}{|c|c|c|c|c|c|}
\hline Product & Policy & Country & $\begin{array}{c}\text { Net welfare } \\
\text { cost/ tCO2 } \\
€\end{array}$ & $\begin{array}{c}\text { Benefits - } \\
\text { costs } \\
€\end{array}$ & $\begin{array}{l}\text { Energy } \\
\text { savings } \\
\text { (GWh) }\end{array}$ \\
\hline Refrigerator & $\begin{array}{l}\text { Energy tax: } \\
\text { further increase } \\
\text { of electricity } \\
\text { price }(10 \%)\end{array}$ & $\begin{array}{l}\text { France } \\
\text { Denmark }\end{array}$ & $\begin{array}{l}-185,5 \\
-10,0\end{array}$ & $\begin{array}{l}3371,8 \\
418,9\end{array}$ & $\begin{array}{l}237 \\
47\end{array}$ \\
\hline $\begin{array}{l}\text { Washing } \\
\text { machine }\end{array}$ & $\begin{array}{l}\text { B class and } \\
\text { lower removed } \\
\text { from the market }\end{array}$ & $\begin{array}{l}\text { Italy } \\
\text { Poland }\end{array}$ & $\begin{array}{l}650,3 \\
190,7\end{array}$ & $\begin{array}{l}-5052113 \\
-2315257\end{array}$ & $\begin{array}{l}26 \\
23\end{array}$ \\
\hline Boiler & $\begin{array}{l}\text { Increase in gas } \\
\text { price }(15 \%)\end{array}$ & $\begin{array}{l}\text { Denmark } \\
\text { Italy }\end{array}$ & $\begin{array}{l}-23,9 \\
-12,1\end{array}$ & $\begin{array}{l}1231331 \\
61634591\end{array}$ & $\begin{array}{l}102 \\
3825\end{array}$ \\
\hline CFLi & $\begin{array}{l}\text { Energy tax: } \\
\text { further increase } \\
\text { in electricity } \\
\text { price }(10 \%)\end{array}$ & $\begin{array}{l}\text { Poland } \\
\text { France }\end{array}$ & $\begin{array}{l}-141,6 \\
-761,3\end{array}$ & $\begin{array}{l}22110662 \\
24613529\end{array}$ & $\begin{array}{l}226 \\
430\end{array}$ \\
\hline
\end{tabular}

* See, footnote in table A1 


\section{CESifo Working Paper Series}

for full list see www.cesifo-group.org/wp

(address: Poschingerstr. 5, 81679 Munich, Germany, office@cesifo.de)

2657 Susanne Neckermann, Reto Cueni and Bruno S. Frey, What is an Award Worth? An Econometric Assessment of the Impact of Awards on Employee Performance, May 2009

2658 Steven Brakman, Harry Garretsen and Charles van Marrewijk, Economic Geography within and between European Nations: The Role of Market Potential and Density across Space and Time, May 2009

2659 Giovanni Facchini and Cecilia Testa, Reforming Legislatures: Is one House better than two?, May 2009

2660 Carsten Kowalczyk and Raymond Riezman, Trade Agreements, May 2009

2661 Oliver Falck, Stephan Heblich and Elke Luedemann, Identity and Entrepreneurship, May 2009

2662 Christian Lessmann and Gunther Markwardt, One Size Fits All? Decentralization, Corruption, and the Monitoring of Bureaucrats, May 2009

2663 Felix Bierbrauer, On the Legitimacy of Coercion for the Financing of Public Goods, May 2009

2664 Alessandro Cigno, Agency in Family Policy: A Survey, May 2009

2665 Claudia M. Buch and Christian Pierdzioch, Low Skill but High Volatility?, May 2009

2666 Hendrik Jürges, Kerstin Schneider, Martin Senkbeil and Claus H. Carstensen, Assessment Drives Learning: The Effect of Central Exit Exams on Curricular Knowledge and Mathematical Literacy, June 2009

2667 Eric A. Hanushek and Ludger Woessmann, Schooling, Cognitive Skills, and the Latin American Growth Puzzle, June 2009

2668 Ourania Karakosta, Christos Kotsogiannis and Miguel-Angel Lopez-Garcia, Does Indirect Tax Harmonization Deliver Pareto Improvements in the Presence of Global Public Goods?, June 2009

2669 Aleksandra Riedl and Silvia Rocha-Akis, Testing the Tax Competition Theory: How Elastic are National Tax Bases in OECD Countries?, June 2009

2670 Dominique Demougin and Carsten Helm, Incentive Contracts and Efficient Unemployment Benefits, June 2009

2671 Guglielmo Maria Caporale and Luis A. Gil-Alana, Long Memory in US Real Output per Capita, June 2009 
2672 Jim Malley and Ulrich Woitek, Productivity Shocks and Aggregate Cycles in an Estimated Endogenous Growth Model, June 2009

2673 Vivek Ghosal, Business Strategy and Firm Reorganization under Changing Market Conditions, June 2009

2674 Francesco Menoncin and Paolo M. Panteghini, Retrospective Capital Gains Taxation in the Real World, June 2009

2675 Thomas Hemmelgarn and Gaëtan Nicodème, Tax Co-ordination in Europe: Assessing the First Years of the EU-Savings Taxation Directive, June 2009

2676 Oliver Himmler, The Effects of School Competition on Academic Achievement and Grading Standards, June 2009

2677 Rolf Golombek and Michael Hoel, International Cooperation on Climate-Friendly Technologies, June 2009

2678 Martin Cave and Matthew Corkery, Regulation and Barriers to Trade in Telecommunications Services in the European Union, June 2009

2679 Costas Arkolakis, A Unified Theory of Firm Selection and Growth, June 2009

2680 Michelle R. Garfinkel, Stergios Skaperdas and Constantinos Syropoulos, International Trade and Transnational Insecurity: How Comparative Advantage and Power are Jointly Determined, June 2009

2681 Marcelo Resende, Capital Structure and Regulation in U.S. Local Telephony: An Exploratory Econometric Study; June 2009

2682 Marc Gronwald and Janina Ketterer, Evaluating Emission Trading as a Policy Tool Evidence from Conditional Jump Models, June 2009

2683 Stephan O. Hornig, Horst Rottmann and Rüdiger Wapler, Information Asymmetry, Education Signals and the Case of Ethnic and Native Germans, June 2009

2684 Benoit Dostie and Rajshri Jayaraman, The Effect of Adversity on Process Innovations and Managerial Incentives, June 2009

2685 Peter Egger, Christian Keuschnigg and Hannes Winner, Incorporation and Taxation: Theory and Firm-level Evidence, June 2009

2686 Chrysovalantou Milliou and Emmanuel Petrakis, Timing of Technology Adoption and Product Market Competition, June 2009

2687 Hans Degryse, Frank de Jong and Jérémie Lefebvre, An Empirical Analysis of Legal Insider Trading in the Netherlands, June 2009

2688 Subhasish M. Chowdhury, Dan Kovenock and Roman M. Sheremeta, An Experimental Investigation of Colonel Blotto Games, June 2009 
2689 Alexander Chudik, M. Hashem Pesaran and Elisa Tosetti, Weak and Strong Cross Section Dependence and Estimation of Large Panels, June 2009

2690 Mohamed El Hedi Arouri and Christophe Rault, On the Influence of Oil Prices on Stock Markets: Evidence from Panel Analysis in GCC Countries, June 2009

2691 Lars P. Feld and Christoph A. Schaltegger, Political Stability and Fiscal Policy - Time Series Evidence for the Swiss Federal Level since 1849, June 2009

2692 Michael Funke and Marc Gronwald, A Convex Hull Approach to Counterfactual Analysis of Trade Openness and Growth, June 2009

2693 Patricia Funk and Christina Gathmann, Does Direct Democracy Reduce the Size of Government? New Evidence from Historical Data, 1890-2000, June 2009

2694 Kirsten Wandschneider and Nikolaus Wolf, Shooting on a Moving Target: Explaining European Bank Rates during the Interwar Period, June 2009

2695 J. Atsu Amegashie, Third-Party Intervention in Conflicts and the Indirect Samaritan's Dilemma, June 2009

2696 Enrico Spolaore and Romain Wacziarg, War and Relatedness, June 2009

2697 Steven Brakman, Charles van Marrewijk and Arjen van Witteloostuijn, Market Liberalization in the European Natural Gas Market - the Importance of Capacity Constraints and Efficiency Differences, July 2009

2698 Huifang Tian, John Whalley and Yuezhou Cai, Trade Sanctions, Financial Transfers and BRIC's Participation in Global Climate Change Negotiations, July 2009

2699 Axel Dreher and Justina A. V. Fischer, Government Decentralization as a Disincentive for Transnational Terror? An Empirical Analysis, July 2009

2700 Balázs Égert, Tomasz Koźluk and Douglas Sutherland, Infrastructure and Growth: Empirical Evidence, July 2009

2701 Felix Bierbrauer, Optimal Income Taxation and Public Goods Provision in a Large Economy with Aggregate Uncertainty, July 2009

2702 Marc Gronwald, Investigating the U.S. Oil-Macroeconomy Nexus using Rolling Impulse Responses, July 2009

2703 Ali Bayar and Bram Smeets, Government Deficits in the European Union: An Analysis of Entry and Exit Dynamics, July 2009

2704 Stergios Skaperdas, The Costs of Organized Violence: A Review of the Evidence, July 2009

2705 António Afonso and Christophe Rault, Spend-and-tax: A Panel Data Investigation for the EU, July 2009 
2706 Bruno S. Frey, Punishment - and beyond, July 2009

2707 Michael Melvin and Mark P. Taylor, The Crisis in the Foreign Exchange Market, July 2009

2708 Firouz Gahvari, Friedman Rule in a Model with Endogenous Growth and Cash-inadvance Constraint, July 2009

2709 Jon H. Fiva and Gisle James Natvik, Do Re-election Probabilities Influence Public Investment?, July 2009

2710 Jarko Fidrmuc and Iikka Korhonen, The Impact of the Global Financial Crisis on Business Cycles in Asian Emerging Economies, July 2009

2711 J. Atsu Amegashie, Incomplete Property Rights and Overinvestment, July 2009

2712 Frank R. Lichtenberg, Response to Baker and Fugh-Berman's Critique of my Paper, "Why has Longevity Increased more in some States than in others?", July 2009

2713 Hans Jarle Kind, Tore Nilssen and Lars Sørgard, Business Models for Media Firms: Does Competition Matter for how they Raise Revenue?, July 2009

2714 Beatrix Brügger, Rafael Lalive and Josef Zweimüller, Does Culture Affect Unemployment? Evidence from the Röstigraben, July 2009

2715 Oliver Falck, Michael Fritsch and Stephan Heblich, Bohemians, Human Capital, and Regional Economic Growth, July 2009

2716 Wladimir Raymond, Pierre Mohnen, Franz Palm and Sybrand Schim van der Loeff, Innovative Sales, R\&D and Total Innovation Expenditures: Panel Evidence on their Dynamics, July 2009

2717 Ben J. Heijdra and Jochen O. Mierau, Annuity Market Imperfection, Retirement and Economic Growth, July 2009

2718 Kai Carstensen, Oliver Hülsewig and Timo Wollmershäuser, Price Dispersion in the Euro Area: The Case of a Symmetric Oil Price Shock, July 2009

2719 Katri Kosonen and Gaëtan Nicodème, The Role of Fiscal Instruments in Environmental Policy, July 2009 